\title{
Exiguobacterium soli sp. nov., a psychrophilic bacterium from the McMurdo Dry Valleys, Antarctica
}

\author{
Preeti Chaturvedi, V. Prabahar, R. Manorama, Pavan Kumar Pindi, \\ Bhaskar Bhadra, Zareena Begum and S. Shivaji
}

Correspondence

S. Shivaji

shivas@ccmb.res.in
Centre for Cellular and Molecular Biology, Uppal Road, Hyderabad 500 007, India

\begin{abstract}
A novel psychrophilic bacterium, designated strain DVS $3 Y^{\top}$, was isolated from a moraine sample from the McMurdo Dry Valleys, Antarctica. Phenotypic and chemotaxonomic characteristics and data from a phylogenetic analysis based on 16S rRNA gene sequences indicated that strain DVS $3 Y^{\top}$ was related to the genus Exiguobacterium. Strain DVS $3 Y^{\top}$ exhibited $>97 \%$ gene sequence similarity with respect to Exiguobacterium acetylicum DSM $20416^{\top}(97.4 \%)$, Exiguobacterium oxidotolerans DSM $17272^{\top}$ (97.4\%), Exiguobacterium indicum IAM $15368^{\top}$ (97.6\%), Exiguobacterium undae DSM $14481^{\top}$ (98.2\%), Exiguobacterium sibiricum DSM $17290^{\top}$ (98.6\%) and Exiguobacterium antarcticum DSM $14480^{\top}$ (99.6\%). However, the levels of DNADNA relatedness between strain DVS $3 Y^{\top}$ and E. acetylicum DSM $20416^{\top}$, E. oxidotolerans JCM $12280^{\top}$, E. indicum IAM $15368^{\top}$, E. undae DSM $14481^{\top}$, E. sibiricum DSM $17290^{\top}$ and $E$. antarcticum DSM $14480^{\top}$ were less than $70 \%(52,25,16,33,16$ and $38 \%$, respectively). Strain DVS $3 Y^{\top}$ also differed from these six closely related species in a number of phenotypic traits. Phenotypic, chemotaxonomic and phylogenetic data suggest that strain DVS $3 Y^{\top}$ represents a novel species of the genus Exiguobacterium, for which the name Exiguobacterium soli sp. nov. is proposed. The type strain is DVS $3 Y^{\top}\left(=\right.$ MTCC $\left.4816^{\top}=J C M 14376^{\top}\right)$.
\end{abstract}

The genus Exiguobacterium was created by Collins et al. (1983) to accommodate a Gram-positive, non-sporeforming, facultatively anaerobic, alkaliphilic bacterium isolated from potato-processing effluent (Gee et al., 1980). At the time of writing, 11 species had been described in this genus: Exiguobacterium aurantiacum (Collins et al., 1983), E. undae and E. antarcticum (Fruhling et al., 2002), E. oxidotolerans (Yumoto et al., 2004), E. aestuarii and E. marinum (Kim et al., 2005), E. mexicanum and E. artemiae (Lopez-Cortes et al., 2006), E. acetylicum (which was transferred from the genus Brevibacterium; Farrow et al., 1994), E. indicum (Chaturvedi \& Shivaji, 2006) and E. sibiricum (Rodrigues et al., 2006). In the present study, strain DVS $3 \mathrm{Y}^{\mathrm{T}}$, a Grampositive, motile, non-spore-forming, rod-shaped bacterium isolated from a moraine sample from Antarctica, was identified as a novel species of the genus Exiguobacterium. Strain DVS $3 \mathrm{Y}^{\mathrm{T}}$ was isolated from a moraine sample collected in December 1995 from the McMurdo Dry

\footnotetext{
The GenBank/EMBL/DDBJ accession number for the 16S rRNA gene sequence of strain DVS $3 Y^{\top}$ is AY864633.

The fatty acid compositions of strain DVS $3 Y^{\top}$ and related species of the genus Exiguobacterium are compared in a supplementary table available with the online version of this paper.
}

Valleys in Antarctica. The sample was transported in ice and stored at $-20{ }^{\circ} \mathrm{C}$ until used for analysis. Following suspension in sterile saline $(150 \mathrm{mM})$, the sample was serially diluted, plated on YPD agar containing yeast extract $(0.5 \%)$, peptone $(1 \%)$, glucose $(2 \%)$ and agar $(1.5 \%)$ and incubated at $25{ }^{\circ} \mathrm{C}$ for 4 days to determine the bacterial density. The sample yielded about 4.5$5 \times 10^{4}$ c.f.u. $\mathrm{ml}^{-1}$. Colonies of strain DVS $3 \mathrm{Y}^{\mathrm{T}}$, which were yellowish orange, were purified by means of repeated streaking and were maintained on ABM agar ( $\mathrm{pH} 7.2)$ containing yeast extract $(1.5 \%)$, peptone $(0.2 \%)$ and agar $(1.5 \%)$ and incubated at $22{ }^{\circ} \mathrm{C}$. ABM agar was also used for the determination of growth at various temperatures $\left(2.5,15,22,28,37\right.$ and $\left.40{ }^{\circ} \mathrm{C}\right), \mathrm{pH}$ values $(4,6,7,8,10$ and 11) and $\mathrm{NaCl}$ concentrations (5, 10 and 15\%) (Shivaji et al., 1989). The buffers used were MOPS (for $\mathrm{pH}$ 6.5-7.9) and CAPS (for $\mathrm{pH}$ 9.7-11.1). Phenotypic characteristics such as colony morphology, cell morphology, motility, various enzyme activities (as listed in Table 1) and sensitivity to antibiotics at $22{ }^{\circ} \mathrm{C}$ were ascertained using standard methods (Lányí, 1987; Smibert \& Krieg, 1994). Gas production was determined according to the method of Hugh \& Leifson (1953). For the determination of acid production, the medium used was phenol red agar base ( $\mathrm{pH} 7.4)$ containing protease peptone (1\%), beef extract 
Table 1. Phenotypic characteristics that serve to differentiate strain DVS $3 Y^{\top}$ from the six most closely related species of the genus Exiguobacterium

Strains: 1, DVS $3 \mathrm{Y}^{\mathrm{T}}$; 2, E. antarcticum DSM $14480^{\mathrm{T}}$; 3, E. sibiricum DSM $17290^{\mathrm{T}}$; 4, E. undae DSM $14481^{\mathrm{T}}$; 5, E. indicum IAM $15368^{\mathrm{T}}$; 6 , E. oxidotolerans JCM $12280^{\mathrm{T}}$; 7, E. acetylicum DSM $20416^{\mathrm{T}}$. All data are from this study unless otherwise indicated. All strains are motile, Grampositive, rod-shaped, do not form endospores, grow at between 10 and $30{ }^{\circ} \mathrm{C}$ (with an optimum at $25{ }^{\circ} \mathrm{C}$ ), tolerate up to $5.8 \% \mathrm{NaCl}$, grow in peptone, fail to grow at $\mathrm{pH} 4$, grow at $\mathrm{pH} 6-10$, are positive in tests for catalase, oxidase, $\beta$-galactosidase, arginine dihydrolase and ornithine decarboxylase and for the Voges-Proskauer test, but are negative for lipase, urease and $\mathrm{H}_{2} \mathrm{~S}$ production and for the indole test. All taxa utilize Dglucose, sucrose, glycerol, dextrin and thioglycolate, but not sorbose, $\mathrm{N}$-acetylglucosamine, polyethylene glycol, D-adonitol, L-phenylalanine, hydroxybutyric acid or sodium propionate. All are negative for acid production from D-sorbitol, D-lactose and L-arabinose. All are sensitive to the following antibiotics $(\mu \mathrm{g})$ : tobramycin (15), lomefloxacin (30), roxithromycin (30), ciprofloxacin (30), lincomycin (15), cefotaxime (30), cefazolin (30), kanamycin (30), novobiocin (30), chloramphenicol (30), ampicillin (25), tetracycline (30), streptomycin (25), erythromycin (15), bacitracin (10), gentamicin G (30), polymyxin B (50), oleandomycin (15), spectinomycin (100), rifampicin (25) and carbenicillin (100). +, Positive; -, negative; ND, not determined; $\mathrm{W}$, weakly positive; R, resistant; s, sensitive; DPG, diphosphatidylglycerol; PE, phosphatidylethanolamine; PG, phosphatidylglycerol; PI, phosphatidylinositol; PS, phosphatidylserine.

\begin{tabular}{|c|c|c|c|c|c|c|c|}
\hline Characteristic & 1 & 2 & 3 & 4 & 5 & 6 & 7 \\
\hline Habitat & $\begin{array}{c}\text { Moraine } \\
\text { sample from } \\
\text { Antarctica }\end{array}$ & $\begin{array}{l}\text { Microbial mat } \\
\text { from a lake in } \\
\text { Antarctica }\end{array}$ & $\begin{array}{l}\text { Siberian } \\
\text { permafrost }\end{array}$ & Garden pond & Glacial water & $\begin{array}{l}\text { Drainage from } \\
\text { fish-proces- } \\
\text { sing plant }\end{array}$ & $\begin{array}{c}\text { Creamery } \\
\text { waste }\end{array}$ \\
\hline Colony size (mm) & $2-3$ & $2-3$ & $2-3$ & $2-4$ & $2-4$ & $1-5$ & $2-5$ \\
\hline Colony shape & Round & Round & Round & Round & Round & Round & Irregular \\
\hline Colony colour & $\begin{array}{c}\text { Yellowish } \\
\text { orange }\end{array}$ & Orange & Orange & Orange & $\begin{array}{c}\text { Yellowish } \\
\text { orange }\end{array}$ & Orange & $\begin{array}{c}\text { Yellowish } \\
\text { orange }\end{array}$ \\
\hline \multicolumn{8}{|l|}{ Growth temperature $\left({ }^{\circ} \mathrm{C}\right)$} \\
\hline 2.5 & + & - & + & - & $\mathrm{W}$ & $\mathrm{W}$ & - \\
\hline 5 & + & - & + & - & + & + & - \\
\hline 37 & - & + & + & + & - & + & $\mathrm{W}$ \\
\hline Maximum growth temperature $\left({ }^{\circ} \mathrm{C}\right)$ & 30 & 41 & 40 & 41 & 30 & 40 & 37 \\
\hline Gelatinase & + & + & + & + & - & + & + \\
\hline DNase & - & + & - & + & - & + & + \\
\hline Caseinase & + & + & + & + & - & + & + \\
\hline Phosphatase & + & + & + & - & + & + & + \\
\hline Lysine decarboxylase & + & - & + & + & + & - & - \\
\hline Arginine decarboxylase & + & + & + & + & + & - & - \\
\hline Tryptophan deamination & - & + & + & - & - & + & + \\
\hline Aesculin hydrolysis & + & + & + & + & - & + & + \\
\hline Starch hydrolysis & + & + & + & + & - & + & + \\
\hline Citrate utilization & - & - & + & - & + & + & + \\
\hline Malonate utilization & - & - & - & - & + & - & - \\
\hline Reduction of nitrate to nitrite & - & - & - & - & + & - & - \\
\hline Methyl red test & - & + & - & + & - & + & + \\
\hline \multicolumn{8}{|l|}{ Acid production from: } \\
\hline Melibiose & - & - & + & - & - & - & - \\
\hline D-Adonitol & - & - & - & - & - & - & + \\
\hline Cellobiose & + & + & - & - & - & - & + \\
\hline D-Fructose & + & + & + & + & - & + & + \\
\hline D-Glucose & + & + & + & + & - & + & + \\
\hline D-Mannose & + & - & + & + & - & + & + \\
\hline Maltose & + & + & + & + & - & + & + \\
\hline D-Ribose & + & + & + & + & - & + & + \\
\hline L-Rhamnose & + & + & - & + & - & + & + \\
\hline Sucrose & + & + & + & + & - & + & + \\
\hline Trehalose & + & + & + & + & - & + & + \\
\hline L-Xylose & + & - & + & - & - & - & - \\
\hline Inulin & + & - & + & - & - & - & - \\
\hline \multicolumn{8}{|l|}{ Carbon source utilization } \\
\hline L-Arabinose & + & - & + & - & - & - & - \\
\hline D-Arabinose & + & - & + & - & - & - & - \\
\hline D-Ribose & + & + & + & + & - & + & + \\
\hline
\end{tabular}


Table 1. cont.

\begin{tabular}{|c|c|c|c|c|c|c|c|}
\hline Characteristic & 1 & 2 & 3 & 4 & 5 & 6 & 7 \\
\hline D-Xylose & + & - & - & - & + & - & - \\
\hline L-Xylose & + & - & - & - & + & - & - \\
\hline D-Galactose & + & - & - & + & + & - & - \\
\hline D-Mannose & + & + & - & + & - & + & + \\
\hline L-Rhamnose & + & - & - & - & + & - & - \\
\hline D-Lactose & + & - & + & - & - & - & - \\
\hline Maltose & + & + & - & + & - & + & + \\
\hline L-Fucose & - & - & - & - & - & - & + \\
\hline Melibiose & + & - & + & - & + & - & - \\
\hline Trehalose & + & + & + & + & - & + & + \\
\hline Melezitose & + & - & - & - & - & - & + \\
\hline Amygdalin & + & + & + & + & - & + & - \\
\hline Arbutin & + & + & - & + & + & + & - \\
\hline Salicin & - & - & ND & + & - & - & + \\
\hline Glycogen & + & + & - & + & + & - & - \\
\hline myo-Inositol & + & - & - & - & + & - & - \\
\hline Dulcitol & + & - & - & - & + & - & - \\
\hline Erythritol & + & - & ND & + & + & + & - \\
\hline D-Mannitol & - & - & - & + & - & + & + \\
\hline D-Sorbitol & + & - & + & - & + & - & - \\
\hline Xylitol & - & - & - & - & - & - & + \\
\hline Methyl $\alpha$-D-mannoside & + & + & - & - & - & - & + \\
\hline Lactic acid & + & - & - & - & + & - & - \\
\hline L-Malic acid & - & - & - & - & + & - & - \\
\hline Valeric acid & - & + & ND & - & + & - & - \\
\hline Sodium acetate & - & + & - & + & + & - & - \\
\hline 5-Ketogluconate & $\mathrm{w}$ & - & - & - & + & - & - \\
\hline Sodium gluconate & - & - & ND & - & + & - & - \\
\hline Sodium fumarate & - & + & ND & - & + & - & - \\
\hline Sodium formate & - & + & ND & - & + & - & - \\
\hline Sodium succinate & - & - & ND & + & + & - & - \\
\hline Potassium acetate & - & - & - & + & + & - & - \\
\hline Sodium pyruvate & + & + & - & + & - & + & + \\
\hline \multicolumn{8}{|l|}{ Amino acid utilization } \\
\hline L-Alanine & + & + & + & + & + & - & - \\
\hline L-Arginine & + & + & + & + & + & - & - \\
\hline L-Aspartic acid & - & - & - & + & + & + & - \\
\hline L-Asparagine & + & + & - & + & + & - & - \\
\hline L-Cysteine & - & + & - & + & - & - & - \\
\hline L-Creatinine & + & - & - & - & + & - & - \\
\hline L-Glycine & + & - & - & + & + & - & - \\
\hline L-Glutamine & + & + & + & + & + & + & - \\
\hline L-Glutamic acid & + & + & + & - & + & - & - \\
\hline L-Histidine & + & + & + & + & + & - & - \\
\hline
\end{tabular}


Table 1. cont.

\begin{tabular}{|c|c|c|c|c|c|c|c|}
\hline Characteristic & 1 & 2 & 3 & 4 & 5 & 6 & 7 \\
\hline L-Isoleucine & + & + & - & + & + & + & - \\
\hline L-Leucine & + & + & - & + & + & - & + \\
\hline L-Lysine & + & + & + & + & + & + & - \\
\hline L-Methionine & - & + & + & + & + & + & - \\
\hline L-Ornithine & + & + & - & + & + & - & - \\
\hline L-Serine & - & - & + & + & + & + & - \\
\hline L-Threonine & - & + & + & + & + & - & - \\
\hline L-Proline & + & + & + & + & + & - & - \\
\hline L-Tryptophan & - & + & ND & - & + & - & - \\
\hline L-Tyrosine & - & + & ND & + & + & - & + \\
\hline L-Valine & - & + & $\mathrm{ND}$ & + & + & - & - \\
\hline \multicolumn{8}{|c|}{ Antibiotic tolerance ( $\mu$ g per disc) } \\
\hline Amikacin (30) & s & s & s & s & $\mathrm{R}$ & s & s \\
\hline Amoxicillin (30) & $\mathrm{R}$ & s & s & s & $\mathrm{R}$ & s & s \\
\hline Clindamycin (25) & s & s & s & s & $\mathrm{R}$ & s & $\mathrm{R}$ \\
\hline Colistin (10) & $\mathrm{R}$ & $\mathrm{R}$ & $\mathrm{R}$ & s & $\mathrm{R}$ & $\mathrm{R}$ & s \\
\hline Doxycycline (25) & $\mathrm{R}$ & s & $\mathrm{R}$ & s & $\mathrm{R}$ & s & s \\
\hline Co-trimoxazole $(25)$ & s & s & s & s & $\mathrm{R}$ & s & s \\
\hline Nalidixic acid (30) & s & s & s & s & $\mathrm{R}$ & s & s \\
\hline Norfloxacin (10) & $\mathrm{R}$ & s & $\mathrm{R}$ & s & $\mathrm{R}$ & s & s \\
\hline Nitrofurantoin (300) & $\mathrm{R}$ & s & s & s & $\mathrm{R}$ & s & s \\
\hline Sulfamethoxazole (50) & $\mathrm{R}$ & s & $\mathrm{R}$ & $\mathrm{R}$ & $\mathrm{R}$ & s & s \\
\hline DNA G $+C$ content $(\mathrm{mol} \%)$ & 48.5 & 47 & $47.7^{\star}$ & 48 & 48 & 47 & 47 \\
\hline Peptidoglycan $\dagger$ & Lys-Gly & ND & Lys-Gly & Lys-Asp & Lys-Gly & Lys-Gly & Lys-Gly \\
\hline Quinone(s) & $\begin{array}{c}\text { MK-6, MK-7, } \\
\text { MK-8 }\end{array}$ & $\begin{array}{c}\text { MK-6, MK-7, } \\
\text { MK-8 }\end{array}$ & $\begin{array}{c}\text { MK-6, } \\
\text { MK-7, MK-8 }\end{array}$ & $\begin{array}{c}\text { MK-6, MK-7, } \\
\text { MK-8 }\end{array}$ & $\begin{array}{r}\text { MK-7, } \\
\text { MK-8 }\end{array}$ & $\begin{array}{c}\text { MK-6, MK-7, } \\
\text { MK-8 }\end{array}$ & MK-7 \\
\hline Polar lipids & $\begin{array}{l}\text { PG, DPG, } \\
\text { PE, PS, PI, } \\
\text { unidentified }\end{array}$ & $\begin{array}{l}\text { PG, DPG, } \\
\text { PE, PS, PI, } \\
\text { unidentified }\end{array}$ & $\begin{array}{c}\text { PG, DPG } \\
\text { PE }\end{array}$ & $\begin{array}{l}\text { PG, DPG, } \\
\text { PE, PS, PI, } \\
\text { unidentified }\end{array}$ & $\begin{array}{l}\text { PG, DPG, } \\
\quad \text { PE (tr) }\end{array}$ & $\begin{array}{l}\text { PG, DPG, } \\
\text { PE, PS, PI, } \\
\text { unidentified }\end{array}$ & DPG, PS \\
\hline
\end{tabular}

${ }^{*}$ Data from Rodrigues et al. (2006).

$\dagger$ Peptidoglycan determinations for strain DVS $3 \mathrm{Y}^{\mathrm{T}}$, E. undae DSM $14481^{\mathrm{T}}$, E. indicum IAM $15368^{\mathrm{T}}$, E. acetylicum DSM $20416^{\mathrm{T}}$ are from this study; those for E. antarcticum DSM $14480^{\mathrm{T}}$, E. sibiricum DSM $17290^{\mathrm{T}}$ and E. oxidotolerans JCM $12280^{\mathrm{T}}$ are from Fruhling et al. (2002), Rodrigues et al. (2006) and Yumoto et al. (2004).

$(0.1 \%), \mathrm{NaCl}(0.5 \%)$, phenol red $(0.0025 \%)$ and agar $(1.8 \%)$. Minimal medium $\left[\mathrm{K}_{2} \mathrm{HPO}_{4}, 1.05 \% \quad(\mathrm{w} / \mathrm{v})\right.$; $\mathrm{KH}_{2} \mathrm{PO}_{4}, 0.45 \%(\mathrm{w} / \mathrm{v}) ;\left(\mathrm{NH}_{4}\right)_{2} \mathrm{SO}_{4}, 0.1 \%(\mathrm{w} / \mathrm{v}) ;$ agar, $1.5 \%(\mathrm{w} / \mathrm{v})]$ was used to evaluate the ability of the culture to assimilate various carbon compounds including amino acids $(0.5 \%, \mathrm{w} / \mathrm{v})$ when provided as sole carbon sources. Fatty acid methyl esters were prepared according to the method of Sato \& Murata (1988) from cells grown on tryptic soy medium (M322; Himedia) at $30{ }^{\circ} \mathrm{C}$ and analysed using the Microbial Identification System (MIDI) according to the protocol described by Agilent Technologies. The $\mathrm{G}+\mathrm{C}$ content of the DNA was determined according to the spectrophotometric method (Shivaji et al., 1989, 2004, 2005). Isoprenoid quinones were extracted following the protocol described by Collins et al. (1977), separated using HPLC and identified as described by Reddy et al. (2003). Peptidoglycan was prepared and analysed according to the method described by Komagata \& Suzuki (1987). DNA-DNA hybridization was performed by using the membrane filter method (Tourova \&
Antonov, 1987), as described previously (Shivaji et al., 1992). E. acetylicum DSM $20416^{\mathrm{T}}$, E. oxidotolerans JCM $12280^{\mathrm{T}}$, E. indicum IAM $15368^{\mathrm{T}}$, E. sibiricum DSM $17290^{\mathrm{T}}$, E. undae DSM $14481^{\mathrm{T}}$ and E. antarcticum DSM $14480^{\mathrm{T}}$ were used as reference strains in studies relating to morphology, biochemical tests and the identification of fatty acids.

To establish the phylogenetic position of strain DVS $3 \mathrm{Y}^{\mathrm{T}}$, DNA was purified and the 16S rRNA gene was amplified and sequenced as described previously (Shivaji et al., 2000; Chaturvedi et al., 2005). The almost-complete sequence of $1518 \mathrm{nt}$ was manually aligned against closely related species by using Clustal W (Thompson et al., 1994). Pairwise evolutionary distances were computed using the DNADIST program with the Kimura two-parameter model, as developed by Kimura (1980). Phylogenetic trees were constructed using the UPGMA and neighbour-joining treemaking algorithms in the PHYLIP package (Felsenstein, 1993). Stability among the clades of the phylogenetic tree 


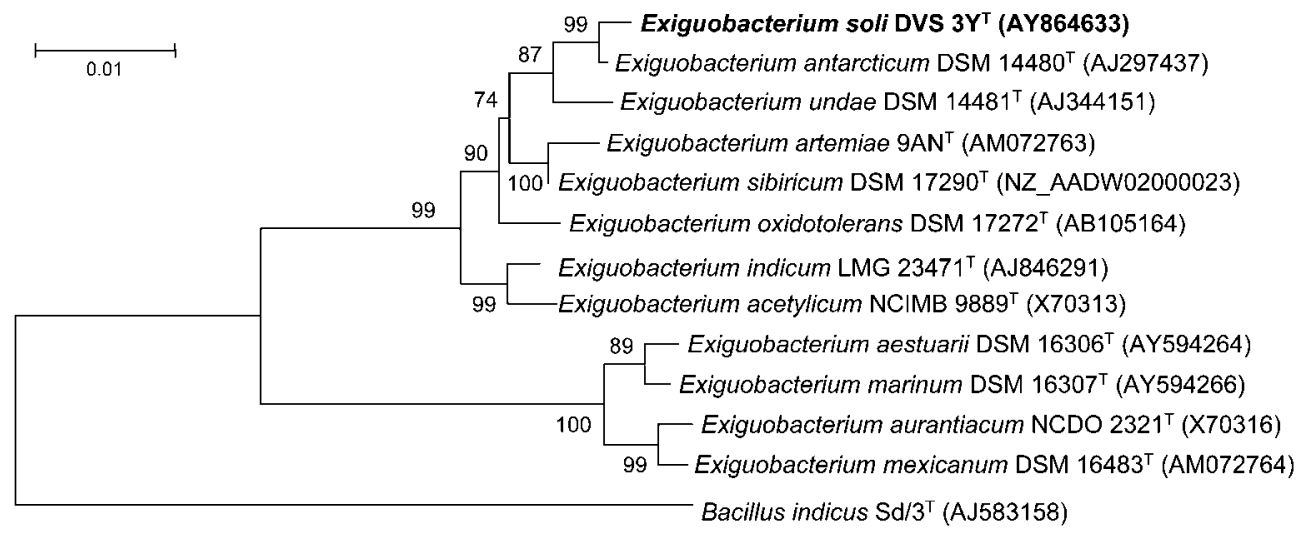

Fig. 1. Neighbour-joining tree based on 16S rRNA gene sequences showing the phylogenetic relationship between strain DVS $3 Y^{\top}$ and species of the genus Exiguobacterium. Bacillus indicus $\mathrm{Sd} / 3^{\top}$ was used as the outgroup. Bootstrap values greater than $50 \%$ are given at the nodes. Bar, 1 substitution per 100 nucleotides.

was assessed by taking 1000 replicates and analysing the dataset using the SEQBOOT, DNADIST, NEIGHBOR and CONSENSE programs in the PHYLIP package.

Phenotypic and chemotaxonomic characteristics of strain DVS $3 \mathrm{Y}^{\mathrm{T}}$ are given in the species description, in Table 1 and in Supplementary Table S1 (available with IJSEM Online). Strain DVS $3 \mathrm{Y}^{\mathrm{T}}$ was found to comprise cells that were Gram-positive, motile, rod-shaped and non-sporeforming, to possess MK-6, MK-7 and MK-8 as the major menaquinones, to possess cell-wall peptidoglycan of the Lys-Gly type and to have a DNA G+C content of $48.5 \mathrm{~mol} \%$; and it was therefore similar to recognized species of the genus Exiguobacterium (Collins et al., 1983; Farrow et al., 1994; Fruhling et al., 2002; Yumoto et al., 2004; Kim et al., 2005; Lopez-Cortes et al., 2006). Phylogenetic analysis based on the 16S rRNA gene sequence (1518 nt) further confirmed the affiliation of strain DVS $3 \mathrm{Y}^{\mathrm{T}}$ to the genus Exiguobacterium (Fig. 1). Strain DVS $3 \mathrm{Y}^{\mathrm{T}}$ formed a robust cluster, with a bootstrap value $>74 \%$ with respect to E. antarcticum DSM $14480^{\mathrm{T}}$, E. undae DSM $14481^{\mathrm{T}}$, E. artemiae DSM $16484^{\mathrm{T}}, E$. sibiricum DSM $17290^{\mathrm{T}}$, E. oxidotolerans JCM $12280^{\mathrm{T}}$, E. indicum HHS $31^{\mathrm{T}}$ and E. acetylicum DSM $20416^{\mathrm{T}}$ (Fig. 1). The remaining strains, E. aestuarii DSM $16306^{\mathrm{T}}, E$. marinum DSM $16307^{\mathrm{T}}$, E. aurantiacum NCDO $2321^{\mathrm{T}}$ and E. mexicanum DSM $16483^{\mathrm{T}}$, formed another clade. The formation of two distinct clades by species of the genus Exiguobacterium has been reported previously (LopezCortes et al., 2006; Kim et al., 2005; Chaturvedi \& Shivaji, 2006).

Using GeneTool 1.0 (http://www.biotools.com/downloads/ content/up_con.html), the 16S rRNA gene sequence similarity of strain DVS $3 \mathrm{Y}^{\mathrm{T}}$ with the recognized species of the genus Exiguobacterium was as follows: $92.5 \%$ with $E$. aestuarii TF-16 ${ }^{\mathrm{T}}$ (GenBank accession no. AY594264), 92.5\% with E. marinum TF-80 ${ }^{\mathrm{T}}$ (AY594266), 93.1\% with E. aurantiacum NCDO $2321^{\mathrm{T}}$ (X70316), 93.6\% with E. mexicanum DSM $16483^{\mathrm{T}}$ (AM072764), $96.8 \%$ with $E$. artemiae DSM $16484^{\mathrm{T}}$ (AM072763), $97.4 \%$ with $E$. acetylicum DSM $20416^{\mathrm{T}}$ (D55730), $97.4 \%$ with E. oxidotolerans DSM $17272^{\mathrm{T}}$ (AB105164), $97.6 \%$ with E. indicum IAM $15368^{\mathrm{T}}$ (AJ846291), $98.2 \%$ with E. undae DSM $14481^{\mathrm{T}}$ (AJ344151), $98.5 \%$ with E. sibiricum DSM $17290^{\mathrm{T}}$ (NZ_AADW02000023) and 99.6\% with E. antarcticum DSM $14480^{\mathrm{T}}$ (AJ297437). Thus, to merit the status of a novel species, strain DVS $3 \mathrm{Y}^{\mathrm{T}}$ must be differentiated from E. acetylicum DSM $20416^{\mathrm{T}}$, E. oxidotolerans DSM $17272^{\mathrm{T}}$, E. indicum IAM $15368^{\mathrm{T}}$, E. undae DSM $14481^{\mathrm{T}}, E$. sibiricum DSM $17290^{\mathrm{T}}$ and E. antarcticum DSM $14480^{\mathrm{T}}$ with which it exhibits $>97 \%$ similarity at the $16 \mathrm{~S}$ rRNA gene level.

At the whole-genome level, as determined by DNA-DNA hybridization, when strain DVS $3 \mathrm{Y}^{\mathrm{T}}$ was radioactively labelled, the levels of DNA-DNA relatedness between strain DVS $3 \mathrm{Y}^{\mathrm{T}}$ and E. acetylicum DSM $20416^{\mathrm{T}}$, E. oxidotolerans JCM $12280^{\mathrm{T}}$, E. indicum IAM $15368^{\mathrm{T}}$, E. undae DSM $14481^{\mathrm{T}}$, E. sibiricum DSM $17290^{\mathrm{T}}$ and E. antarcticum DSM $14480^{\mathrm{T}}$ were $52,25,16,33,16$ and $38 \%$, respectively. However, when E. acetylicum DSM $20416^{\mathrm{T}}$, E. oxidotolerans JCM $12280^{\mathrm{T}}$, E. indicum IAM $15368^{\mathrm{T}}$, E. undae DSM $14481^{\mathrm{T}}$, E. sibiricum DSM $17290^{\mathrm{T}}$ and E. antarcticum DSM $14480^{\mathrm{T}}$ were labelled and used for DNA-DNA hybridization with DVS $3 \mathrm{Y}^{\mathrm{T}}$ in the reciprocal reaction, the similarities were 42, 23, 23, 39, 24 and $33 \%$, respectively.

Strain DVS $3 \mathrm{Y}^{\mathrm{T}}$ differed from the above six phylogenetically closely related species in terms of a number of phenotypic characteristics (Table 1) and also exhibited significant quantitative differences with regard to fatty acid content (see Supplementary Table S1 in IJSEM Online). The predominant fatty acids were iso- $\mathrm{C}_{13: 0}(16.1 \%)$, iso$\mathrm{C}_{15: 0}(17.1 \%)$, iso- $\mathrm{C}_{16: 0}(4.1 \%)$, iso- $\mathrm{C}_{17: 0}(10.6 \%)$, anteiso- $\mathrm{C}_{13: 0}(15.2 \%)$, anteiso- $\mathrm{C}_{15: 0}$ (6.2\%), anteiso$\mathrm{C}_{17: 0}(3.3 \%)$ and $\mathrm{C}_{16: 0}(3.6 \%)$. These iso- and anteisofatty acids constituted $>63 \%$ of the total fatty acids in 
strain DVS $3 Y^{\mathrm{T}}$, E. sibiricum DSM $17290^{\mathrm{T}}$, E. undae DSM $14481^{\mathrm{T}}$, E. indicum IAM $15368^{\mathrm{T}}$ and E. oxidotolerans JCM $12280^{\mathrm{T}}$. These Exiguobacterium species (with the exception of $E$. undae DSM $14481^{\mathrm{T}}$ ) grow at $5{ }^{\circ} \mathrm{C}$, unlike the other species. Thus, these iso- and anteiso- fatty acids may be required for growth at low temperatures. According to the criteria generally used for discriminating species (Stackebrandt \& Goebel, 1994), strain DVS 3Y ${ }^{\mathrm{T}}$, which exhibits $<70 \%$ similarity at the DNA-DNA level with respect to E. acetylicum DSM $20416^{\mathrm{T}}$, E. oxidotolerans JCM $12280^{\mathrm{T}}$, E. indicum IAM $15368^{\mathrm{T}}$, E. undae DSM $14481^{\mathrm{T}}, E$. sibiricum DSM $17290^{\mathrm{T}}$ and E. antarcticum DSM $14480^{\mathrm{T}}$ (the most closely related species) and which also differs phenotypically from these six species (Table 1 and Supplementary Table S1), represents a novel species in the genus Exiguobacterium. The name Exiguobacterium soli sp. nov. is proposed for this novel species.

\section{Description of Exiguobacterium soli sp. nov.}

Exiguobacterium soli sp. nov. (so'li. L. gen. n. soli of soil).

Cells are aerobic, Gram-positive, motile and rod-shaped ( $1.9 \mu \mathrm{m}$ in length and $0.95 \mu \mathrm{m}$ in width). Stationary-phase cells are coccobacillary in shape $(1.5 \mu \mathrm{m}$ in length and $1.15 \mu \mathrm{m}$ in diameter). Colonies $(2-3 \mathrm{~mm})$ on nutrient agar are round, shiny, irregular, elevated and yellowish orangecoloured after $24 \mathrm{~h}$ at $22{ }^{\circ} \mathrm{C}$. No spores are observed. Growth occurs between 2.5 and $30{ }^{\circ} \mathrm{C}$ and at $\mathrm{pH}$ 6-10. The optimum temperature and $\mathrm{pH}$ for growth are $25{ }^{\circ} \mathrm{C}$ and 7.0. $\mathrm{NaCl}$ is tolerated at $5.8 \%$ and growth also occurs in the absence of salt. Positive in tests for catalase, oxidase, $\beta$ galactosidase, phosphatase, arginine dihydrolase, lysine decarboxylase, ornithine decarboxylase, arginine decarboxylase, gelatinase, caseinase, malonate utilization, aesculin hydrolysis and starch hydrolysis and in the Voges-Proskauer test. Negative for urease, lipase, DNase, tryptophan deamination, nitrate reduction to nitrite, citrate utilization, indole production, $\mathrm{H}_{2} \mathrm{~S}$ production and in the methyl red test. The following are utilized: D-glucose, D-fructose, D-galactose, Dlactose, maltose, D-mannose, L-rhamnose, raffinose, trehalose, D-ribose, melibiose, melezitose, cellobiose, sucrose, D-xylose, L-xylose, L-arabinose, D-arabinose, glycerol, D-sorbitol, dulcitol, starch, inulin, dextrin, myo-inositol, glycogen, sodium thioglycolate, methyl $\alpha$-D-mannoside, amygdalin, arbutin, lactic acid, pyruvate, erythritol, $\gamma$-glucuronic acid, $\alpha$-ketoglutaric acid, 5-ketogluconate, L-glycine, L-ornithine, L-alanine, L-leucine, L-isoleucine, L-lysine, L-arginine, L-glutamic acid, Lglutamine, L-asparagine, L-proline, L-histidine, L-creatinine. The following are not utilized: L-fucose, L-sorbose, Dmannitol, D-adonitol, hydroxybutyric acid, dextran, sodium gluconate, sodium fumarate, sodium formate, sodium succinate, sodium propionate, sodium acetate, polyethylene glycol, potassium acetate, cellulose, methyl $\alpha$-D-glucoside, methyl- $\alpha$-D-galactoside, methyl $\beta$-D-galactoside, $N$-acetylglucosamine, salicin, xylitol, citric acid, fumaric acid, L-malic acid, valeric acid, L-aspartic acid, L-cysteine, L-methionine, Lserine, L-threonine, L-tyrosine, L-tryptophan, L-valine and Lphenylalanine. Acid is produced from cellobiose, D-fructose,
D-glucose, D-mannose, maltose, D-ribose, L-rhamnose, sucrose, trehalose, L-xylose and inulin, but not from D-sorbitol, melibiose, D-lactose, L-arabinose or D-adonitol. Resistant to the following antibiotics $(\mu \mathrm{g})$ : amoxicillin (30), colistin (10), doxycycline (25), norfloxacin (10), nitrofurantoin (300) and sulfamethoxazole (50). Sensitive to the following antibiotics $(\mu \mathrm{g})$ : co-trimoxazole (25), clindamycin (25), amikacin (30), nalidixic acid (30), tobramycin (15), lomefloxacin (30), roxithromycin (30), ciprofloxacin (30), lincomycin (15), cefotaxime (30), cefazolin (30), kanamycin (30), novobiocin (30), chloramphenicol (30), ampicillin (25), tetracycline (30), streptomycin (25), erythromycin (15), bacitracin (10), gentamicin G (30), polymyxin B (50), oleandomycin (15), spectinomycin (100), rifampicin (25) and carbenicillin (100). The respiratory quinones are MK-6, MK-7 and MK- 8 and the cell-wall peptidoglycan is of the Lys-Gly type. Phosphatidylglycerol, diphosphatidylglycerol, phosphatidylethanolamine, phosphatidylserine and phosphatidylinositol and an unidentified lipid are present. The fatty acids present are iso- $\mathrm{C}_{12: 0}(2.0 \%), \mathrm{C}_{12: 0}(1.4 \%)$, iso- $\mathrm{C}_{13: 0}(16.1 \%)$, anteiso$\mathrm{C}_{13: 0}(15.2 \%)$, iso- $\mathrm{C}_{14: 0}(2.3 \%), \mathrm{C}_{14: 0}(1.3 \%)$, iso- $\mathrm{C}_{15: 0}$ $(17.1 \%)$, anteiso- $\mathrm{C}_{15: 0}(6.2 \%), \mathrm{C}_{15: 1} \omega 5 c(2.2 \%)$, iso- $\mathrm{C}_{16: 0}$ $(4.1 \%) \mathrm{C}_{16: 0}(3.6 \%), \mathrm{C}_{16: 1} \omega 11 c(0.7 \%)$, anteiso- $\mathrm{C}_{17: 1} \omega 9 c$ $(1.3 \%)$, iso- $\mathrm{C}_{17: 0}(10.6 \%)$, iso- $\mathrm{C}_{17: 1} \omega 10 c(2.3 \%)$, anteiso$\mathrm{C}_{17: 0}(3.3 \%), \mathrm{C}_{18: 0} 10$ methyl $(1.1 \%), \mathrm{C}_{19: 0}(2.7 \%)$, summed feature $1(1.8 \%)$, summed feature $3(1.7 \%)$, summed feature $4(0.8 \%)$ and summed feature $8(2.2 \%)$.

The type strain, DVS $3 Y^{\mathrm{T}}\left(=\right.$ MTCC $\left.4816^{\mathrm{T}}=\mathrm{JCM} 14376^{\mathrm{T}}\right)$, was isolated from a moraine sample from the McMurdo Dry Valleys, Antarctica. The DNA G $+\mathrm{C}$ content of the type strain is $48.5 \mathrm{~mol} \%$.

\section{Acknowledgements}

We are grateful to the National Centre for Antarctic and Ocean Research (Government of India, Goa) for a research grant awarded to S.S.

\section{References}

Chaturvedi, P. \& Shivaji, S. (2006). Exiguobacterium indicum sp. nov., a psychrophilic bacterium from the Hamta glacier of the Himalayan mountain ranges of India. Int J Syst Evol Microbiol 56, 27652770.

Chaturvedi, P., Reddy, G. S. N. \& Shivaji, S. (2005). Dyadobacter hamtensis sp. nov., from Hamta glacier, located in the Himalayas, India. Int J Syst Evol Microbiol 55, 2113-2117.

Collins, M. D., Pirouz, T., Goodfellow, M. \& Minnikin, D. E. (1977). Distribution of menaquinones in actinomycetes and corynebacteria. J Gen Microbiol 100, 221-230.

Collins, M. D., Lund, B. M., Farrow, J. A. E. \& Schleifer, K. (1983). Chemotaxonomic study of an alkalophilic bacterium, Exiguobacterium aurantiacum gen. nov., sp. nov. J Gen Microbiol 129, 2037-2042.

Farrow, J. A. E., Wallbanks, S. \& Collins, M. D. (1994). Phylogenetic interrelationships of round-spore-forming bacilli containing cell walls based on lysine and the non-spore-forming genera Caryophanon, Exiguobacterium, Kurthia and Planococcus. Int J Syst Bacteriol 44, 74-82. 
Felsenstein, J. (1993). PHYLIP (phylogeny inference package) version 3.5.1. Distributed by the author. Department of Genome Sciences, University of Washington, Seattle, USA.

Fruhling, A., Schumann, P., Hippe, H., Straubler, B. \& Stackebrandt, E. (2002). Exiguobacterium undae sp. nov. and Exiguobacterium antarcticum sp. nov. Int J Syst Evol Microbiol 52, 1171-1176.

Gee, J. M., Lund, B. M., Metcalf, G. \& Peel, J. L. (1980). Properties of a new group of alkalophilic bacteria. J Gen Microbiol 117, 9-17.

Hugh, R. \& Leifson, E. (1953). The taxonomic significance of fermentative versus oxidative metabolism of carbohydrates by various gram negative bacteria. J Bacteriol 66, 24-26.

Kim, I.-G., Lee, M.-H., Jung, S.-Y., Song, J. J., Oh, T.-K. \& Yoon, J.-H. (2005). Exiguobacterium aestuarii sp. nov. and Exiguobacterium marinum sp. nov., isolated from a tidal flat of the Yellow Sea in Korea. Int J Syst Evol Microbiol 55, 885-889.

Kimura, M. (1980). A simple method for estimating evolutionary rates of base substitutions through comparative studies of nucleotide sequences. J Mol Evol 16, 111-120.

Komagata, K. \& Suzuki, K. (1987). Lipid and cell-wall analysis in bacterial systematics. Methods Microbiol 19, 161-207.

Lányí, B. (1987). Classical and rapid identification methods for medically important bacteria. Methods Microbiol 19, 1-67.

Lopez-Cortes, A., Schumann, P., Pukall, R. \& Stackebrandt, E. (2006). Exiguobacterium mexicanum sp. nov. and Exiguobacterium artemiae sp. nov. isolated from the brine shrimp Artemia franciscana. Syst Appl Microbiol 29, 183-190.

Reddy, G. S. N., Matsumoto, G. I. \& Shivaji, S. (2003). Sporosarcina macmurdoensis sp. nov., from a cyanobacterial mat sample from a pond in the McMurdo Dry Valleys, Antarctica. Int J Syst Evol Microbiol 53, 1363-1367.

Rodrigues, D. F., Goris, J., Vishnivetskaya, T., Gilichinsky, D., Thomashow, M. F. \& Tiedje, J. M. (2006). Characterization of Exiguobacterium isolates from the Siberian permafrost. Description of Exiguobacterium sibiricum sp. nov. Extremophiles 10, 285-294.

Sato, N. S. \& Murata, N. (1988). Membrane lipids. In Methods in Enzymology, vol. 167, pp. 251-259, Edited by L. Packer \& A. N. Glazer. New York: Academic Press.
Shivaji, S., Rao, N. S., Saisree, L., Reddy, G. S. N., Seshu Kumar, G. \& Bhargava, P. M. (1989). Isolates of Arthrobacter from the soils of Schirmacher Oasis, Antarctica. Polar Biol 10, 225-229.

Shivaji, S., Ray, M. K., Rao, N. S., Saisree, L., Jagannadham, M. V., Kumar, G. S., Reddy, G. S. N. \& Bhargava, P. M. (1992). Sphingobacterium antarcticus sp. nov. a psychrotrophic bacterium from the soils of Schirmacher Oasis, Antarctica. Int J Syst Bacteriol 42, 102-106.

Shivaji, S., Vijaya Bhanu, N. \& Aggarwal, R. K. (2000). Identification of Yersinia pestis as the causative organism of plague in India as determined by $16 \mathrm{~S}$ rDNA sequencing and RAPD-based genomic fingerprinting. FEMS Microbiol Lett 189, 247-252.

Shivaji, S., Reddy, G. S. N., Raghavan, P. U. M., Sarita, N. B. \& Delille, D. (2004). Psychrobacter salsus sp. nov. and Psychrobacter adeliensis sp. nov. isolated from fast ice from Adelie Land, Antarctica. Syst Appl Microbiol 27, 628-635.

Shivaji, S., Chaturvedi, P., Reddy, G. S. N. \& Suresh, K. (2005). Pedobacter himalayensis sp. nov., from the Hamta glacier located in the Himalayan mountain ranges of India. Int J Syst Evol Microbiol 55, 1083-1088.

Smibert, R. M. \& Krieg, N. R. (1994). Phenotypic characterization. In Methods for General and Molecular Bacteriology, pp. 607-654. Edited by P. Gerhardt. Washington, DC: American Society for Microbiology.

Stackebrandt, E. \& Goebel, B. M. (1994). Taxonomic note: a place for DNA-DNA reassociation and 16S rRNA sequence analysis in the present species definition in bacteriology. Int J Syst Bacteriol 44, 846849.

Thompson, J. D., Higgins, D. G. \& Gibson, T. J. (1994). CLUSTAL W: improving the sensitivity of progressive multiple sequence alignment through sequence weighting, position-specific gap penalties and weight matrix choice. Nucleic Acids Res 22, 4673-4680.

Tourova, T. P. \& Antonov, A. S. (1987). Identification of microorganisms by rapid DNA-DNA hybridization. Methods Microbiol 19, 333355.

Yumoto, I., Narisawa, M. H., Hirota, K., Shingyo, T., Takebe, F., Nodasaka, Y., Matsuyama, H. \& Hara, I. (2004). Exiguobacterium oxidotolerans sp. nov., a novel alkaliphile exhibiting high catalase activity. Int J Syst Evol Microbiol 54, 2013-2017. 